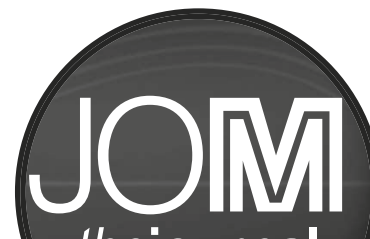

thejournal

\title{
2015 and 2016 editorial calendar
}

\section{August 2015}

Theme: Advanced Modeling and Characterization

- In-Situ Mechanical Testing in Electron Microscopes

- Advances in Modeling of Solidification Microstructures

- New Horizons in Mechanical Spectroscopy

- CALPHAD-Based ICME Research for Materials Genomic Design

Manuscripts Due: Deadline Passed

\section{September 2015}

Theme: Energy and Environment

- Sustainability in Metallurgy

- Materials for Solar Applications

- Lead and Zinc Metallurgy

- Energy Materials: Synthesis, Characterization, and Applications

- Aluminum: Recycling and Environmental Issues

- MEMA 2015

Manuscripts Due: Deadline Passed

\section{October 2015}

Theme: Physical Metallurgy

- Phase Transformations and Microstructural Evolution: Part I

- Progress in High-Entropy Alloys

- Progress with Lead-Free Solders

- Age-Hardenable Microalloying in Magnesium

Manuscripts Due: Deadline Passed

\section{November 2015}

Theme: Materials for Energy and Extreme Environments

- Materials Degradation in Light-Water Reactors

- Optimizing Energy in Industrial Furnaces

- High-Temperature Corrosion of Ni-Base Alloys

- Advances in Refractory Metals

- Surfaces and Biointerfaces: Part II

- Recycling of Materials

Manuscripts Due: Deadline Passed

\section{December 2015}

Theme: Materials: Past, Present, and Future

- Stability of Nanomaterials

- Futuristic Nanomaterials and Composites

- Nanomechanical Measurements in Harsh Environments

- Aluminum: Cast Shop and Alloys

- Archaeomaterials

- Dynamic Probing of Microstructure Evolution in Nanostructured Materials

Manuscripts Due: August 15, 2015

\section{January 2016}

Theme: Applying Materials Science and Engineering

- Futuristic Nanomaterials and Composites: Part II

- ICME: Bridging Interfaces

- In-Situ Mechanical Testing in Electron Microscopes: Part II

- Phase Transformations and Microstructural Evolution: Part II

Manuscripts Due: August 15, 2015

\section{February 2016}

Theme: Energy and Processing

- Extractive Metallurgy: Efficiency and Eco-Friendliness

- The Canadian Generation IV Supercritical Water-Cooled Nuclear Reactor Conceptual Design

- Functional Nanomaterials: Energy and Sensing

- Aluminum: Bauxite-Alumina-Carbon-Reduction

Manuscripts Due: September 15, 2015

\section{March 2016}

Theme: Additive Manufacturing

- Progress in Additive Manufacturing

- Advances in Sintering

- Rapid Solidification and Phase Transformation in Additive Manufactured Materials

Manuscripts Due: October 15, 2015

\section{April 2016}

Theme: Biomaterials and Thin Films

- Biomaterials for Healthcare

- Recent Developments in Functional Thin Films

Manuscripts Due: November 15, 2015 


\section{5 advisors and committees}

\author{
Amit Pandey \\ Advanced Characterization, Testing, \& \\ Simulation Committee \\ Michael Gao \\ Alloy Phases Committee
}

Alton Tabereaux, Pascal Lavoie, and John Griffin

Aluminum Committee

Candan Tamerler

Biomaterials Committee

Fadi Abdeljawad and Stephen Foiles Chemistry \& Physics of Materials Committee

Muralidharan Paramsothy Composite Materials Committee

Bala Radhakrishnan Computational Materials Science \&

Engineering Committee

Kinga Unocic (2015)

Vilupanur A. Ravi (2016)

Corrosion \& Environmental Effects Committee

Babak Arfaei

Electronic Packaging \& Interconnection Materials Committee

Geoff Brooks

Energy Committee

Xiaochuan Lu

Energy Conversion \& Storage

Committee

\author{
Chantal Sudbrack \\ High Temperature Alloys Committee \\ Takanari Ouchi \\ Hydrometallurgy \& Electrometallurgy \\ Committee
}

Georg Schmitz

ICME Committee

James Saal (2015)

Dmytro Orlov (2016)

Magnesium Committee

Orlando Rios

Magnetic Materials Committee

Jian Li

Materials Characterization Committee

Marian S. Kennedy

Mechanical Behavior of Materials Committee

Terry Xu and Jung-Kun Lee Nanomaterials Committee

Xiaodong Li and

Peter Hosemann (2015)

Jian Li (2016)

Nanomechanical Materials Behavior Committee

Ramprashad Prabhakaran

Nuclear Materials Committee

Amy Clarke

Phase Transformations

Committee
Ma Qian

Powder Materials Committee

Ed Herderick

Process Technology \& Modeling Committee

Zhiwei Peng and

Dean Gregurek

Pyrometallurgy Committee

Gabrielle Gaustad (2015)

Randy Kirchain (2016)

Recycling \& Environmental

Technologies Committee

Todd Leonhardt

Refractory Metals \& Materials

Committee

Yuri Hovanski

Shaping \& Forming Committee

Mohsen Asle Zaeem

Solidification Committee

Sandip Harimkar and

Srinivasa Bakshi (2015)

Narendra Dahotre, Benjamin Boesl, and Hitesh Vora (2016)

Surface Engineering Committee

Roger Narayan

Thin Films \& Interfaces Committee

Anyone wishing to publish in JOM should follow the guidelines established in the JOM Instructions for Authors, which features detailed information on communication, manuscript preparation, and publication procedures. The Instructions for Authors are available on the JOM website at jom.tms.org.

For More Information Contact:

Telephone: (724) 776-9000 ext. 228

e-mail: jom@tms.org 